\title{
Modeling Primary Production in the NORTH SEA
}

\author{
By Andreas Moll
}

$\mathrm{T}$ HE NORTh SEA IS part of the north-west European Shelf of the North Atlantic. The circulation is counterclockwise and shows a strong dependency on the open boundaries. Nutrient inputs from the Atlantic, the rivers, the sediments and the Wadden Sea cause areas of high productivity. Observations show low production zones in the stratified regions and higher production in the well-mixed areas. The minimum annual primary production observed was $40-79 \mathrm{gC} \mathrm{m}^{-2} \mathrm{y}^{-1}$ off the British coast and the maximum values $>261 \mathrm{gC} \mathrm{m}^{-2} \mathrm{y}^{-1}$ in the German Bight. Much higher values ( $>370 \mathrm{gC} \mathrm{m}^{-2} \mathrm{y}^{1}$ ) were observed in the Wadden Sea. Although there have been large observational programs (Charnock et al., 1994; Sündermann 1994), the capacity of ship and man power is not enough to study the different regional primary production cycles. One way to estimate primary production is the use of a numerical model if all the necessary forcing is available.

The focus of my dissertation was to merge a water column model of the phytoplankton-phosphate dynamics (Radach and Moll, 1993) with a transport model (Pohlmann, 1991) into a three-dimensional primary production model for the North Sea (Moll, 1995). The aim was to use the model as a tool to quantify the regional productivity on an annual basis. Primary production is limited in the model by solar radiation, nutrient phosphate, and zooplankton grazing from prescribed monthly mean copepod biomass. The horizontal grid size of the numerical model is $20 \times 20$ square kilometer, the vertical resolution is $5 \mathrm{~m}$ for the upper $50 \mathrm{~m}$ and increasing layer thickness below $50 \mathrm{~m}$ up to a maximum of 19 layers.

The forcing for the model is as close as possible to the actual year 1986, to include the physical short-term variability that determines the phytoplankton system. The most prominent feature of the North Sea dynamics for annual studies is the residual circulation (integration over the tidal

Institut für Meereskunde, Zentrum für Meeres- und Klimaforschung. Universität Hamburg, Troplowitzstr. 7, D-22529 Hamburg, Germany, Ph.D. 1995 (advisor: G. Radach). cycle). A three-dimensional baroclinic circulation model (Pohlmann 1996) provided the daily mean velocities and eddy diffusivities that were used to advect and diffuse the components of the biological model. Phosphate regeneration occurred in the pelagic zone and through a simple parameterization at the bottom via a benthic detritus pool. Solar radiation was calculated every $30 \mathrm{~min}$ for each grid point by an octa-model using daily cloud data (Pätsch 1994). The underwater light is modified by self-shading.

The focus of this article is to present the results of the model in the context of the resulting phytoplankton fields, the model validation, and their associated net primary production cumulatively over $1 \mathrm{yr}$. The phytoplankton spring bloom (Fig. 1) starts in March in the coastal zone, over the shallow Dogger Bank, and off the Norwegian coast (an area with strong salinity line stratification) and migrates from April to early May into the deeper parts of the North Sea following the bathymetry.

For the model validation all available chlorophyll and phosphate observations aggregated for 15 boxes (Fig. 2) were used to provide monthly mean box values with the measured range as $17 \%$ - and $83 \%$-quantil values presented as bars. As an example, the simulated and observed concentrations are shown for Box 1 in the northern North Sea. Simulated annual cycles of the phosphate concentrations in Box I are in the observed range (Fig. 2a). The chlorophyll concentrations are a little too high in summer, but the amount and onset of the spring and autumn bloom is in good agreement with observations (Fig. 2b). For comparison to net daily production literature values were collected and presented in the same way. Simulated daily net primary production lies very well in the range of observed production values except the winter months (Fig. 2c). The simulated annual cycles of the stratified northern and central North Sea (Boxes 1-4) agree well with the observed mean values. The annual cycles of the coastal boxes differ from each other. Especially in the coastal boxes with shallow water depth (Boxes 7-9) the spring bloom occurs 1 mo too 
(a)

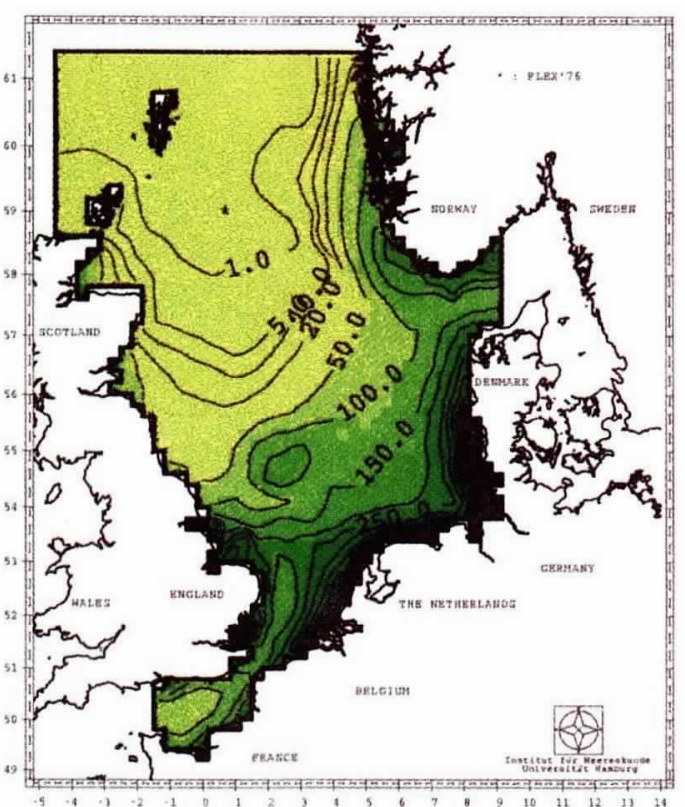

(b)

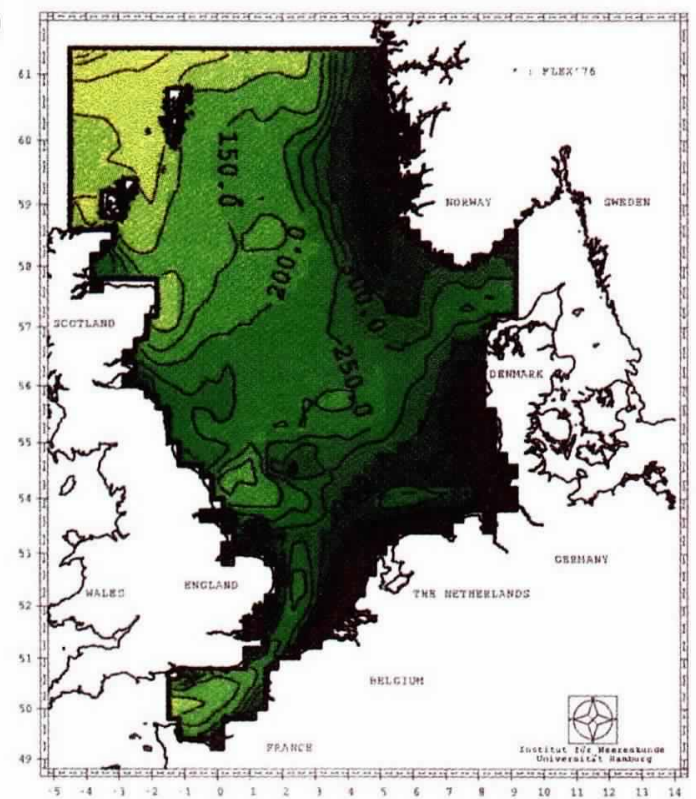

Fig. 1: Horizontal distribution of the phytoplankton concentration in $\mathrm{mgC} \mathrm{m}^{-3}$ for (a) March and (b) April in the surface layer.

early, probably due to the absence in the model of attenuation caused by terrigenous suspended matter. During the summer period the phosphate cycles in the shallow boxes of the continental coast (Box 8) are overestimated by the model, because benthic remineralization is too strong due to the constant regeneration factor. Altogether, the collected data sets show that the model reproduces the regional structure of the phytoplankton dynamics.

The net primary production estimates by the three-dimensional model are presented in Figure 3. (a)
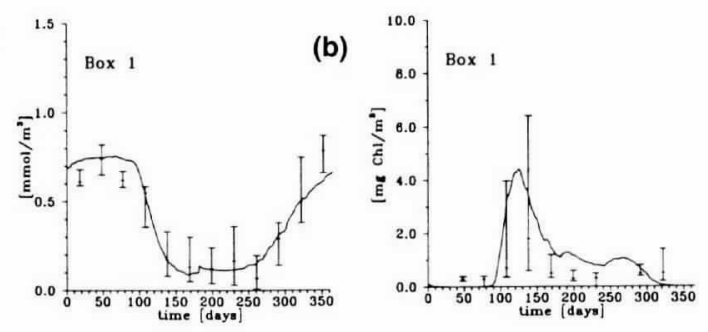

(c)
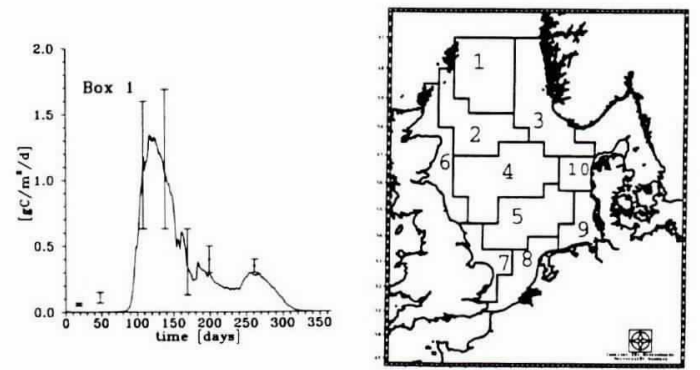

Fig. 2: Separation of the model domain into boxes for model validation. Simulated (line) and observed (bars) concentrations are shown for Box 1 in the northern North Sea. (a) phosphate, (b) chlorophyll, and $(\boldsymbol{c})$ daily net primary production.

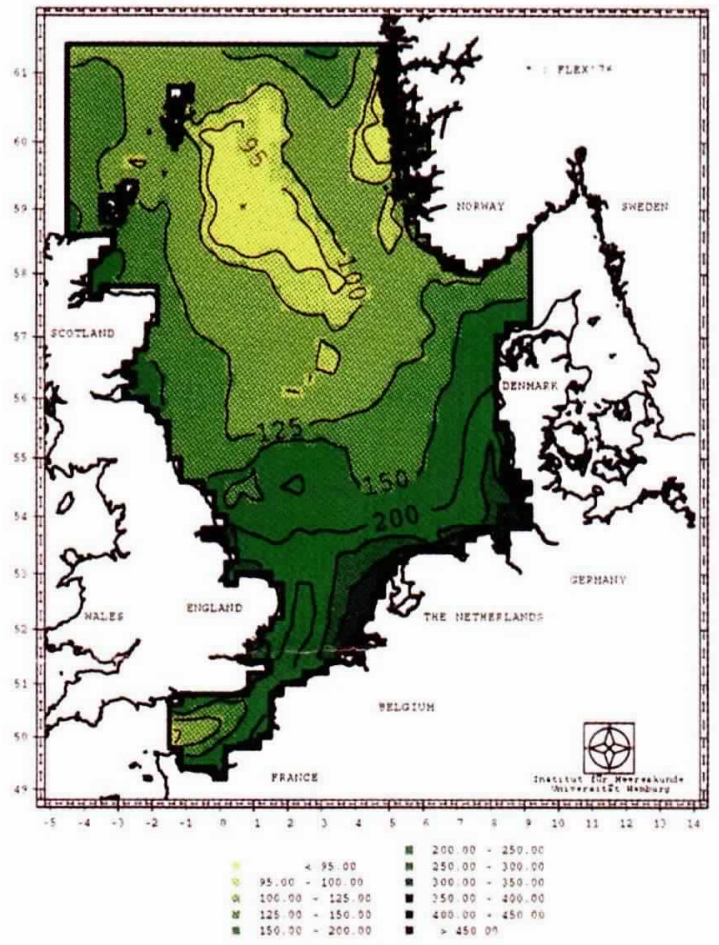

Fig. 3: Simulated annual net primary production in $\mathrm{gC} \mathrm{m}^{-2} \mathrm{y}^{-1}$ for 1986.

The regions of largest production are the coastal zone off The Netherlands $\left(>300 \mathrm{gC} \mathrm{m}^{-2} \mathrm{y}^{-1}\right)$, the German Bight ( $>250 \mathrm{gC} \mathrm{m}^{-2} \mathrm{y}^{-1}$ ), and the Dogger Bank area $\left(>200 \mathrm{gC} \mathrm{m}^{-2} \mathrm{y}^{-1}\right)$. Lowest production values of $95-100 \mathrm{gC} \mathrm{m}^{-2} \mathrm{y}^{-1}$ occur in the central northern North Sea where the Fladen Ground Ex- 
periment (FLEX'76) took place in spring 1976. The three-dimensional simulation now shows that water column models validated with FLEX'76 data were so successful because the central northern North Sea is hardly influenced by nutrient sources (almost no advectional contributions as in the coastal areas), and because of the strong vertical stratification, production values are low and in good agreement with one-dimensional model results. On the other hand the simulated production field for the whole North Sea area suggests that, as a result of advection, nutrient sources such as river inputs and the sediments, intensify productivity in the coastal areas where isolines form a narrow band with increasing gradients to the coast. A simulation scenario without horizontal advection and diffusion showed that primary production is strongly intensified by advected nutrients in all coastal zones around the North Sea.

With the use of these estimates, the mean primary production of the stratified area is $119 \mathrm{gC}$ $\mathrm{m}^{-2} \mathrm{y}^{-1}$ and $199 \mathrm{gC} \mathrm{m}^{-2} \mathrm{y}^{-1}$ for the coastal areas, while the mean primary production of the whole North Sea is $145 \mathrm{gC} \mathrm{m}^{-2} \mathrm{y}^{-1}$. This value is a little greater than the suggested value of $130 \mathrm{gC} \mathrm{m}^{-2} \mathrm{y}^{-1}$ (Jones, 1984), which is necessary to supply the food requirements of the higher trophic levels of the North Sea ecosystem.

The three-dimensional primary production model is the simplest model for the analysis of the phytoplankton dynamics, the phosphorus transports, and the primary productivity in the North Sea. The model, based on a simple phosphorus cycle, took into account only two pelagic variables (phytoplankton and phosphate), used the simplest parameteriza- tion for pelagic and benthic regeneration, and prescribed the copepod biomass for the trophic edge of zooplankton. The model impresses by the results despite its simplicity. A full description of the simulation of 1986 is given in Moll (1995), and a model animation is available on the World Wide Web under http://ifmaix 7.ifm.uni-hamburg.de/kino.html or on disk from the author.

\section{References}

Charnock, H., K.R. Dyer, J.M. Huthnance, P.S. Liss, J.H. Simpson, and P.B. Tett, eds., 1994: Understanding the North Sea System. Chapman \& Hall, London, $222 \mathrm{pp}$.

Jones, R., 1984: Some observations on energy transfer through the North Sea and Georges Bank food webs. Rapp. P.-v. Réun. Cons. Perm. Int. Explor. Mer., 183, 204-217.

Moll. A.. 1995: Regionale Differenzierung der Primärproduktion in der Nordsee: Untersuchungen mit einem drei-dimensionalen Modell. Berichte aus dem Zentrum für Meeres- und Klimaforschung; Reihe B; Ozeanographie, 19. $151 \mathrm{pp}$.

Pätsch. J., 1994: MOCADOB a Model Generating Synthetical Time Series of Solar Radiation for the North Sea. Berichte aus dem Zentrum für Meeres- und Klimaforschung; Reihe B: Ozeanographie, $16,67 \mathrm{pp}$.

Pohlmann, T., 1991: Untersuchung hydro- und thermodynamischer Prozesse in der Nordsee mit einem dreidimensionalen numerischen Modell. Berichte aus dem Zentrum für Meeres- und Klimaforschung, 23. $116 \mathrm{pp}$.

Pohlmann. T., 1996: Calculating the annual cycle of the vertical eddy viscosity in the North Sea with a three-dimensional baroclinic shelf sea circulation model. Continent. Shelf Res., 16, 147-161.

Radach, G. and A. Moll, 1993: Estimation of the variability of production by simulating annual cycles of phytoplankton in the central North Sea. Prog. Oceanogr., 31. $339-419$.

Sündermann, J., ed., 1994: Circulation and Contaminant Fluxes in the North Sea. Springer-Verlag, Berlin, 654 pp. 